\title{
1 Jumping onto the galloping horses - even in India
}

The first major work to challenge the role of governments in education was E.G. West's Education and the State, published in 1965 by the Institute of Economic Affairs (IEA). West was the first to really question the accepted wisdom of the role of the state by looking back into British and US history.

At the first meeting of the Mont Pelerin Society (MPS) in 1947 a group of 39 liberals, made up of economists, philosophers, historians, political scientists and jurists, discussed a range of potentially damaging issues that were threatening Western liberal civilisation. Friedrich A. Hayek, one of the leading free market and Austrian economists who had gained acclaim owing to his 1944 publication Road to Serfdom, invited the 39 to the first meeting. The group highlighted six main aims of the MPS with a central issue of "combating the misuse of history for the furtherance of creeds hostile to liberty'. ${ }^{1}$ Indeed four years later the 1951 MPS meeting solely focused on how opponents of capitalism, such as Marx and Engels, had distorted the history of capitalism in the industrial revolution in Britain and the US. According to Hayek, historical facts were being misrepresented in order for the socialist cause to be strengthened. It was important for work to be done by the members of the MPS, along with others, to seek out the true facts and overturn some historical fallacies. West attended his first MPS meeting in 1962 and was to be influenced by MPS founders and members, primarily Milton Friedman but also James Buchanan and Gordon Tullock. Milton Friedman had already suggested the use of education vouchers in 1955, and Friedman and West entered into some lengthy discussions regarding education and the role of the state. As for Buchanan and Tullock, they were the founding figures of public choice theory, predicting the behaviour of government bureaucracies, recognising that politicians are self-interested utility maximising individuals. And in that case their political decisions may not necessarily represent what is best for the public good, but their own self-interest; 'the political machinery is seen, in fact, largely as operated by interest groups, vote-maximising politicians and self-seeking bureaucracies. ${ }^{2}$ West also was deeply taken with Hayek's concern regarding historical fallacies and the way history was being used by socialists to forward their ideas and policies. 
The second part of this chapter will summarise West's thesis and findings with regard to education in England before the state began to fund and provide schools. The central argument being that there is a gross misunderstanding of historical fact with regard to schooling prior to state involvement and provision of schools. In fact, before state intervention there was a flourishing private schooling system that catered for the poor as well as the rich. This is still relatively unknown owing to a misguiding and misinterpretation of historical artefacts, data and records. However, the evidence from West's work is presented here to try to rectify some of these misconceptions.

What West would have been excited about is the de facto privatisation of schooling in India and other developing countries. He did not really live long enough to appreciate all the empirical work and research that was about to be undertaken. West died just weeks before he was to attend a lecture given in his honour planned to take place at Newcastle University in 2001. What was about to be uncovered in the years after his death mirrored the historical discoveries of West's own research. So not only were West's hypotheses borne out by historical evidence but what was found in the slums and low-income areas of India mirrored what had been occurring in England in the early nineteenth century.

West also did not know about the British 'uprooting the beautiful tree' of India's indigenous education system in the early 1800s. Census and survey data gathered by Sir Thomas Munro, who became the governor of the Madras Presidency in 1819, provide evidence to show the destruction of all that was good with regard to education at that time. The first part of this chapter looks at this evidence and its implications, showing inextricably linked historical episodes of private schools' markets being replaced by a publically provided and run monopoly.

\section{BEFORE THE RAJ - THE INDIA EXPERIENCE}

\section{Uprooting the Beautiful Tree}

On 20 October 1931, during a three-month stay in England, Mahatma Gandhi gave a talk at Chatham House, London. Here he revealed something interesting:

I say without fear of my figures being challenged successfully, that today India is more illiterate than it was fifty or a hundred years ago, and so is Burma, because the British administrators, when they came to India, instead of taking hold of things as they were, began to root them out. They scratched the soil and began to look at the root, and left the root like that, and the beautiful tree perished. ${ }^{3}$ 
Fascinating in itself, claiming that the British had come to India and started to destroy an already flourishing indigenous education system. He continued:

The village schools were not good enough for the British administrator, so he came out with his programme. Every school must have so much paraphernalia, building, and so forth. ${ }^{4}$

According to Gandhi, the British came with their 'expensive' and overly prescriptive state-funded, state-provided, state-regulated system where a school was only deemed functional if it provided certain facilities, most of which may not have contributed to quality and in fact were alien to the surroundings of nineteenth-century India. Gandhi claimed there were data, gathered by Sir Thomas Munro, to show operational unrecognised (unregulated) private schools prior to any British intervention:

There are statistics left by a British administrator which show that, in places where they have carried out a survey, ancient schools have gone by the board, because there was no recognition for these schools, and the schools established after the European pattern were too expensive for the people, and therefore they could not possibly overtake the thing. ${ }^{5}$

So Gandhi believed that owing to the implementation of a state schooling system in India, by the British, the population was now more illiterate than before. Offering schools funded, provided and regulated by the state was an expensive method that India could not afford. The indigenous schooling system, which was successfully educating children in the villages of India, was destroyed by the British:

I defy anybody to fulfil a programme of compulsory primary education of these masses inside of a century. This very poor country of mine is ill able to sustain such an expensive method of education. Our state would revive the old village schoolmaster and dot every village with a school both for boys and girls. ${ }^{6}$

So on what evidence was Gandhi basing his claims? How many such schools were there? How were they funded? And, what quality of education did they provide for those who accessed them?

\section{Indigenous Education in Nineteenth-Century India - Quantity}

In the summer of 1822 a survey and census of education in India was initiated by 'Munro's Minute', also known as a memorandum entitled 'Ordering the Collection of Detailed Information of Indigenous Education'. ${ }^{7}$ Munro set out in the memorandum to make it clear that 
opinions regarding indigenous education were, up until then, built on 'mere conjectures of individuals unsupported by any authentic documents', and as such should be provided 'little attention'. ${ }^{8}$ What Munro was suggesting was to undertake an education survey, similar to previous geographical and agricultural surveys carried out in the Madras Presidency, to find out more about the population and their 'resources'. According to Munro, in 1822 there was 'no record to show the actual state of education throughout the country' 9 and this proposed survey would 'enable us to form an estimate of the state of instructions among the people'. ${ }^{10}$ In this regard Munro was asking the district collectors to make lists of schools in which reading and writing were taught. Within each of these schools, information was to be collected on the number of scholars attending, their caste, the books read, school timings, and 'the monthly or yearly charge to the scholars'.$^{11}$ Interestingly and importantly, Munro goes on to say towards the end of his memorandum that:

it is not my intention to recommend any interface whatever in the native schools. Everything of this kind ought to be carefully avoided, and the people should be left to manage their schools in their own way. ${ }^{12}$

So just to be clear, Munro was requesting a survey of schooling. The intention was to have an official document that set out information that currently was not available. It was not the purpose to change, improve, take over or interfere with what was functioning already on the ground.

So what did the census and survey data show?

The data from 20 districts of the Madras Presidency took between one and three years to make its way back to Munro. Within those districts, 11,575 schools were located catering for 157,195 children. ${ }^{13}$ Figures were also provided by some of the collectors who believed that many children were receiving education in their homes. Home schooling, Munro believed, was very common in the presidency. For example, the Collector of Madras discovered that there were five times more children educated in their homes than in school, the figures being 26,963 and 5699 respectively.

In March 1826 Munro produced a summary of the data, estimating that over one-third of male school-aged children was being educated, either in school or at home. It was more difficult to provide figures for girls, with the majority having been thought to receive education in the home rather than in school. What the evidence showed was that in India the number of children benefitting from education was 'higher than it was in most European countries'. ${ }^{14}$ Not only did the education system cater for the elite, but it also catered for the poorest children (dalit or backward caste) making up in some districts around one-third of school enrolments. 
Munro was not the only one to gather data on India's indigenous education. Another survey was carried out in the British Presidency of Bengal, the result of which was published in 1841 as the 'State of Education in Bengal 1835 to $1838^{\prime}$ and became part of the documents known as the Adam Reports. The findings showed that there were 'some 100,000 such schools in Bengal and Bihar'15 and that:

the system of village schools is extensively prevalent; that the desire to give education to their male children must be deeply seated in the minds of parents even of the humblest classes; and that these are the institutions, closely interwoven as they are with the habits of the people and the customs of the country. ${ }^{16}$

The same was true in the Punjab and Bombay.

In the Presidency of Bombay it was documented by senior officials that 'there is hardly a village, great or small, throughout our territories, in which there is not at least one school, and in larger villages more'. ${ }^{17}$ That is, private schools. The same was true for the Punjab.

Census data therefore from the Presidencies of Madras, Bombay, Bengal and the Punjab show a flourishing indigenous education system operating in India before the British replaced it. Children were being educated both in school and at home, some children remaining in education for 10-12 years. ${ }^{18}$ The system was comparable to that which operated in European countries.

But who was paying for it and how much did it cost?

\section{Indigenous Education in Nineteenth-Century India - Cost}

Looking back at the data with regard to education funding supplied by 19 of the collectors of the Madras Presidency, 16 of the reports show that schooling was 100 per cent privately funded. The remaining three collectors provided data that show that around 98-99 per cent of schools were privately funded with only 1-2 per cent supported by the state.

Data collected from 630 private primary schools surveyed by one of the collectors shows that some private schools offered teaching in the local language, others in Persian and finally some in English. Only 15 of the 630 schools in his district did not charge fees. Fees seemed to differ depending upon the medium of instruction, with the English-medium schools charging the most. Of those teaching in the local language fees ranged from 15 annas ${ }^{19}$ to 21 rupees per year (collected on a monthly basis), the fee-paying Persian schools charged between 14 annas and 24 rupees per year, and the English private schools from 7.5 rupees to 42 rupees per year. In general fees were charged relevant to the child's educational stage; the higher 
up the educational ladder one climbed the higher the fee. Also, poorer students were often charged a small proportion of the full fee. Evidence of such private school philanthropy or the giving of scholarships for the poor is set out in William Adam's report from Bengal 1835-1838:

Another mode adopted in two instances, of regulating the fees is according to the means of the parents whose children are instructed; a half, a third, or a fourth less being charged to the children of poor than to the children of rich parents in the successive stages of instruction. ${ }^{20}$

And a letter to the board of revenue in 1825 from the 'Collector from Madras Cutcherry' (an L.G.K. Murray) also indicates that the poor pay less for their education:

It will be observed that the schools now existing in the country are for the most part supported by the payments of the people who send their children to them for instruction. The rate of payment for each scholar varies in different districts and according to the different circumstance of the parents of the pupils, from 1 anna to 4 rupees per mensem, the ordinary rate among the poorer classes appears to be generally about 4 annas, and seldom to exceed $1 / 2$ rupee. ${ }^{21}$

So if education existed and parents were able to pay for it why did the British want to replace it with something Gandhi regarded as unsustainable and inferior? What were the arguments they used to 'uproot' this beautiful tree?

\section{Indigenous Education in Nineteenth-Century India - Sir Philip Hartog}

Listening to Gandhi's talk at Chatham House was Sir Philip Hartog, founder of the School of Oriental Studies, University of London and ex-vice chancellor of the University of Dacca. He was positively fuming regarding Gandhi's claims and remarks. A lengthy debate was entered into, Hartog requesting Gandhi to revoke his comments. So incensed was Hartog that he gave a series of lectures to dismiss Gandhi's claims regarding the flourishing private system uprooted by the British. Hartog set out to question the data concerning both the quantity and quality of education available. His main aim was to dispel any doubt that may have been instigated by Gandhi's talk. He wanted to show that what the British had introduced provided more access and better quality than what existed previously.

Owing to what can only be described as Hartog's prejudices, the suggestion was that the original figures regarding the number of private schools and children attending school were exaggerated and inaccurate. So upon what foundation was Hartog basing his argument? 
With regard to quantity, Hartog simply took the collectors' reports that suited his needs, dismissing the rest. It is relatively easy to dismiss Hartog's interpretation, therefore, of the data regarding the quantity of schooling, as it is all so well documented by Munro and the Adam Reports. Blatantly Hartog just used the data he found most fitting to bolster his argument, dismissing the rest as exaggerated. If Hartog were correct about an exaggeration, one would actually have to ask why individual collectors would inflate such figures. It was neither in their interest to over or under estimate the number of schools they found. It is easy to ascertain that Hartog only considered one or two of the collectors' reports in his presentation of the data to support his misguiding of historical fact.

But what about the quality of these schools? Was Hartog right to question the quality of the private schools? And was this so-called lack of quality a good enough reason for them to be replaced by a school system funded and provided by the state?

There are two ways to try to uncover what the quality of these low-cost private schools must have been like. First, parents, including poor parents, were paying for their children to be educated. If the quality of schooling or the education attained was so poor, as suggested by Hartog, then why were parents prepared to send their children for such a protracted amount of time and at such a cost? Parents would surely be acting rationally, as self-interested individuals. Hartog's attitude then dismisses the parents' ability to judge for themselves the benefits education brings, as well as the value judgements that go with the decision to send their children to gain an education rather than carry out some other activity. Therefore the rationality and self-interest of parents towards education seems to imply that the quality of 'schooling' for them at least was adequate.

Second, what about the written evidence surrounding quality? In the original census and survey carried out by Munro there had been no requirement to comment on the quality of the schools. Such judgements would anyway have been subjective as no testing was being carried out. However, six of the 20 collectors did provide comments on school quality. The majority of these comments were positive.

In a report from 29 October 1822, the assistant collector in charge at Seringapatam (an H. Vibart) noted that:

the extent of information acquired under the present prevailing system of education is extremely limited - nothing more is professed to be taught in these day-schools than reading, writing, and arithmetic, just competent for the discharge of the common daily transactions of society. ${ }^{22}$

This actually could be taken as a positive comment; that is, reading, writing and arithmetic were competently taught and learnt, which 
would allow the children to participate in their communities and within society.

L.G.K. Murray, the collector from Madras, was very positive in his report of November 1822, stating in his fourth and fifth points that:

it is generally admitted that before they attain their thirteenth year of age, their acquirement in the various branches of learning are uncommonly great, a circumstance very justly ascribed to an emulation and perseverance peculiar only to the Hindoo castes ... Astronomy, Astrology, etc., are in some instances taught to the children of the poorer class. ${ }^{23}$

In 1823, the North Arcot District Collector William Cooke commented that schooling also had a positive effect, allowing children to gain employment in different occupational circumstances:

The Tamil, Taloogoo and Hindwy schools are the most extensive; to these the scholars are sent generally about the age of 5 and in the course of five or six years are generally found sufficiently forward to commence assisting in the preparation or copying of the accounts, according to their different walks in life, sometimes as volunteers in the public Cutcherries or in the situations with Curnums, Shroffs, Merchants or others, whence they graduate to situations in the public service or their hereditary occupations. ${ }^{24}$

Agreeing with Cooke, J.F. Lane, the collector from Masulipatam, in 1823 believed the children gained an education that also allowed them to take up placements in employment. Describing the pedagogy and the process thus:

They are first taught to read the letters, spelling, and the names both common and proper, writing on the sand with their fingers. When they are perfect in that, they are taught the reading of books (Balaramayanum, Amram, etc.), on cadjans (useful for the boys) in Sanscrit and Gentoo as well as letters of correspondence, books of mathematics, accounts, etc., etc., according to the pleasure of the relations of the boys... As soon as the boys have learnt to write well on cadjans or on paper they are removed from the schools to some of the public or private offices of curnums, paishcar, or to be improved in keeping accounts, or to schools of foreign languages such as Persian, English, etc. ${ }^{25}$

However the remaining two collectors, S. Smalley and A.D. Campbell were a little more critical:

Few of the schoolmasters are acquainted with the grammar of the language, which they profess to teach, and neither the master nor scholars understand the meaning of the sentences, which they repeat ... Education cannot well, in a civilized state, be on a lower scale than it is and I much fear there does not exist the same desire for improvement as is reported of the natives of Bengal. ${ }^{26}$ 
However, Smalley does go on to note that there was no intention to 'interfere with the people in the mode of education'27 and that the British were only considering providing some kind of aid to those private institutions that already existed.

So even though it is very difficult to ascertain from these few comments the true 'quality' of instruction that was actually taking place in the schools and homes at the time, it would seem fair to say that parents were satisfied, prepared to pay and allow their children to attend rather than carry out some other duty or role. Therefore the opportunity cost of sending one's child to school must have been such that it was of benefit not only to the child, but the family. The majority of the collectors who commented on quality had positive things to say. So it is difficult to ascertain from the reports why Hartog believed that the quality was poor and that the British needed to intervene to upgrade and improve the system. What was also pertinent was that within these reports it was made quite clear that the indigenous education should remain intact.

So if the quantity and quality proved to be adequate then what could Hartog hang his coat onto? Also highlighted by the Adam survey in Bengal were issues and details around teacher pay, buildings and pedagogy.

Regarding teacher remuneration, Adam believed that teachers in Bengal were paid a poor wage (owing to minimal fees paid by the parents) and therefore this must imply that the most engaging and appropriately qualified teachers were not being attracted to the profession:

The teachers depend entirely upon their scholars for subsistence, and being little respected and poorly rewarded, there is no encouragement for persons of character, talent or learning to engage in the occupation. ${ }^{28}$

However, the pay teachers were receiving was not considered low at that time compared to other opportunities. It was just that Adam believed that teachers were entitled to receive an amount greater than that determined by the market:

I have spoken of the emoluments of the teachers as low; but I would be understood to mean that they are low, not in comparison with their qualifications, or with the general rates of similar labour in the district, but with those emoluments to which competent men might be justly considered entitled. ${ }^{29}$

Not much wrong there then.

With regard to school buildings, the reports noted that education took place in a number of spaces including places of worship, private dwellings, in the open air and in other parts of the village. This implied that typically there was not one building exclusively utilised for the purpose of schooling, 
which according to Adam brought certain 'disadvantages'. But surely the fact that there were no purpose-built schools implied the efficient and effective use of space allowing for an affordable form of education?

Having teachers being paid the market rate and education being carried out utilising other buildings or appropriate spaces should be considered a good thing?

And how about pedagogy then, could Hartog be onto something there? The Adam Reports urged generally that teaching methods used in the private schools should be 'abandoned' ${ }^{30}$ But oddly enough they state that they better equip the scholars with the skills needed to participate within society than schools in Scotland! So why replace the methods if superior to that in Britain?

Other reports from Bombay talk about the simplicity, effectiveness, as well as the economy, of learning in the private schools; ${ }^{31}$ commending methods that lead to the ability for the learner to be accurate, competent, clear and concise. Peer teaching was used extensively throughout India, where the 'Master' relays knowledge to the older or brighter students who in turn communicate the information to the younger or less capable children who are learning in groups. This method had been observed and catalogued in India from as early as 1623 by Peter Della Valle ${ }^{32}$ and was regarded as an effective 'wisdom of crowds' type pedagogy. Indeed, so good was the method of peer teaching that when Dr Andrew Bell encountered it in 1787 he copied the idea and brought the method back to England some ten years later. Bell published a description of the 'Madras Method' as he called it upon his return to England and the system was adopted in British schools, including the Lancasterian schools created by Joseph Lancaster.

So why replace something that seemed to be working?

There was no doubting the quantity and (looking at the reports of the day) quality with regard to learning, effectiveness and efficiency, which seem more than adequate. Teacher pay was driven by market rates and education was regarded as something that could take place in a multitude of spaces without the need to build specific places of learning which would have been costly. Indeed, so successful were the pedagogical methods used in India, they were brought back to England to be implemented in British schools.

It would seem from the evidence that Hartog's dismissal of Gandhi's claims was more based on his own preference for education being centrally provided, funded and controlled as opposed to private and indigenous. Hartog would not be able to reconcile any thought that the British could have intervened if there were no reasons to. Hartog's manipulation of the historical facts during his presentations was misleading and 
misrepresentative. Whatever the reason for which the British 'uprooted the beautiful tree' of indigenous education in India, it was not because it was inadequate. As stated by Gandhi during his talk at Chatham House, irrespective of all of this evidence and irrespective of the promises not to intervene, the British were about to do exactly that. Munro, before the census collection, had stated that it was not his intention to interfere with what was found, allowing the schools to be managed in a way suitable to their context. At all costs any interference was to be 'carefully avoided'. ${ }^{33}$

Things were to change in 1835 .

Thomas Babington Macaulay, the president of the General Committee of Public Instruction for the British Presidency, recommended 'uprooting the beautiful tree' and setting up a system of publically funded village schools. According to Macaulay, in 1835:

The great object of the British Government ought to be the promotion of European literature and science among the natives of India, and that all the funds appropriated for the purposes of education would be best employed on English education alone. ${ }^{34}$

Macaulay was hugely dismissive of the private indigenous schools and the content being taught within the system. His recommendations and comments, irrespective of the work set out by Munro, the Adam Reports and others from Bombay, led in 1854 to the setting up of a state education system with state-funded teacher training, universities, the provision of funds for colleges and high schools, and funds that would bring the private schools under state control. It was something that Hartog defended and Gandhi vociferously challenged as too costly and unnecessary. The British introduced a system, when in fact they had sworn they would not, that crowded out indigenous education in India.

Little did Hartog and Gandhi know that in the new millennium parent power would be reversing imperialism, reclaiming education in order for the beautiful tree to begin again to be nurtured.

But what was happening in England around this time? Did a private schools system exist in parallel in the villages of Yorkshire and Northumberland just as it did in Madras, Bengal and the Punjab? Leaving the shores of India, where state education was just beginning, evidence was also being collected in England, just as in India, revealing an educated populace without the state. 


\section{EDUCATION AND THE STATE IN ENGLAND}

E.G. West's Education and the State was first published in 1965. What West argues in the book is that before 1870, when the major state intervention into education in England and Wales began, school attendance and literacy rates were above 90 per cent. Obviously causing impassioned debate at the time, the book and its thesis were reviewed in several publications and newspapers, not only in developed countries, but discussions even reached India. According to the Economic Times of India on 31 January 1966, West's Education and the State:

deserves to be read ... it is undoubtedly worthwhile for policy-makers, even in the socialistic political culture of India, to be aware of a line of argument which undoubtedly stems from a totally different historical situation. ${ }^{35}$

Interestingly, as is set out in this chapter, the evidence with regard to schooling in India prior to the British imposing a state system there shows that the assumption made by the Economic Times of India regarding a 'totally different historical situation' is misplaced. The historical situation with respect to schooling in India is actually inextricably linked to that in England and Wales. Another book review written in India concerning Education and the State, revealed among E.G. West's papers after his death, noted:

At a time when the private sector in education in India is threatened with extinction ... Dr West furnishes a powerful armoury of arguments against Statism in education. Conditions in India differ radically from those in England, but to us as to those in that distant island the same choice between freedom and totalitarianism in education has been presented. ${ }^{36}$

So, as in the work of Dharampal above, how did E.G. West come to the assumptions he did? That is, that prior to state intervention in schooling in England and Wales, the USA and other countries education of the poor was met by the private sector without the support of the state. West looks at literacy rates (inferring the ability to read and write) and the quantity of schooling using quantitative evidence from parliamentary debates as well as anecdotal evidence from the period. Two main dates are important here; 1833 saw the first government subsidies to education, provided through taxation, and 1870 saw the Forster Act, which instigated the provision of Board Schools, funded partly by the state. 


\section{Literacy}

Anecdotal evidence supports the thesis that literacy amongst the English population before the introduction of state-supported schooling was in fact high. With regard to literacy in the first 33 years of the nineteenth century, West states that 'the effect of state activity upon individual efforts to become literate was one of deliberate hindrance'. ${ }^{37}$ What West believed the English government wanted to do was to prevent the spread of political literature among the poor. Therefore fiscal and legal action was taken against newspapers, especially those that were critical of government. At the time, Tom Paine's Rights of Man had sold one and a half million copies. Reading also took place in the home, with the Bible being read extensively, as well as popular literature and serialised fiction. The government felt that it needed to suppress the spread of some kinds of literature and therefore try to contain what the 'lower orders' were reading. To stifle the reading of such potentially damaging publications, public reading rooms were closed down and licences withdrawn from coffee houses, public houses and inns where certain newspapers were received and read.

What more formal data from the early nineteenth century show is that before the state became involved in education, schools taught children to read before they learnt to write. Learning to read at the time was considered more important as the need to write was quite limited, especially before the introduction of the penny post in 1840 . Writing was also expensive owing to the taxes that were placed on writing materials. Reading therefore was the main focus of education.

Looking at the literacy rates amongst different sections of society, the data shows that a high proportion of people were literate. First, 87 per cent of children between the ages of nine and 16 years living in the workhouses of Norfolk and Suffolk in 1838 could read and 53 per cent could write. ${ }^{38}$ Second, 79 per cent of miners in 1840 from Northumberland and Durham could read, with more than half being able to write. ${ }^{39}$ Third, a report looking at education in 1839 in the borough of Kingston upon Hull found that out of 14,526 adults, 14,109 had attended a day or evening school and 92 per cent of all adults could read. ${ }^{40}$ These adults would have been around 15 years old when the first government subsidies were introduced in schools in 1833. Most would have left school by the age of 11. Their ability to read was not fostered through government support but by non-government sources, mainly through parents paying fees for their children to be educated. By the 1860s it is believed that nine out of ten people in England could read. According to the figures, when the 1870 Board Schools (government schools) began to operate 93 per cent of school leavers were already literate. State intervention into schooling did 
not instigate literacy. Literacy levels were already high. There was therefore no justification for the state to get involved in schooling with regard to literacy levels amongst its citizens. The private and philanthropic educational institutions were already ensuring that the majority were literate.

\section{Nineteenth-Century Private Schools in England}

So prior to the introduction of Board Schools and the Forster Act of 1870, 93 per cent of school leavers were already literate. Government subsidies to education started in 1833 and amounted to a total of $£ 20,000$ given to just two voluntary school organisations, the National Society and the British and Foreign School Society. In 1869, irrespective of almost 40 years of subsidy, 'two thirds of school expenditure was still coming from voluntary sources, especially from the parents, directly or indirectly'. ${ }^{41}$ The remaining third would have come from taxation, which was more burdensome on the working classes owing to its regressive nature.

In the early nineteenth century there were different private agencies within which learning could take place. These included the Mechanics Institute, the Literary and Philosophic Societies, Sunday schools as well as tuition being carried out in the home. And there were also private schools, deriving their income from privately paid fees without any degree of public support. James Mill noted, in the Edinburgh Review of 1813, around the period of the Napoleonic war:

From observation and inquiry assiduously directed to that object, we can ourselves speak decidedly as to the rapid progress which the love of education is making among the lower orders in England. Even around London, in a circle of fifty miles radius, which is far from the most instructed and virtuous part of the kingdom, there is hardly a village that has not something of a school; and not many children of either sex who are not taught more or less reading and writing. We have met with families in which, for weeks together, not an article of sustenance but potatoes had been used; yet for every child the hard-earned sum was provided to send them to school. ${ }^{42}$

The number of children in school, funded by non-government means, including parents paying fees, increased from around 478,000 in 1818 to $1,294,000$ in 1834 without any input from the state. Henry Brougham, in a speech to the House of Lords in May 1835, warned that owing to the increase in schooling and the numbers of children attending, the government would need to take the 'greatest care' when interfering with it:

[w] here we have such a number of schools and such means of education furnished by the parents themselves from their own earnings and by the contributions of well disposed individuals in aid of those whose earnings 
were insufficient, it behoves us to take the greatest care how we interfere with a system which prospers so well of itself; to think well and long and anxiously, and with all circumspection and all foresight, before we thrust our hands into a machinery which is now in such a steady, constant, and rapid movement; for if we do so in the least degree incautiously, we may occasion ourselves no little mischief, and may stop that movement which it is our wish to accelerate. ${ }^{43}$

By 1851 there were 2,144,378 children in day schools. The 1851 census shows that 85 per cent of these were in private schools, that is, according to the census 'all schools which derive their income solely from (fee) payments or which are maintained with a view to pecuniary advantage'. 44 The remaining 15 per cent were attending schools that were 'supported in any degree' by the state and at that time this could have implied minimum support.

In 1858 the Newcastle Commission on Popular Education was set up to carry out a survey and census of schooling in England and Wales. Reporting in 1861 it showed a total of 2,535,462 children in school. Using an estimate of children being in school for 5.7 years, this implied that almost all children were in school. According to the report:

Wherever the Assistant Commissioners went, they found schools of some sort, and failed to discover any considerable number of children who did not attend school for some time, at some period in their lives. ${ }^{45}$

The report goes on to advise that the provision of schooling was such that there were no serious gaps in provision and therefore did not recommend the provision of state schools, but to improve the payment of direct grants to independent schools along with the inspection of private schools. According to West:

the general theme was the control and encouragement of the existing private framework rather than the political creation of new types of collectively organised schools. ${ }^{46}$

The commission reported:

The proportion of children receiving instruction to the whole population is, in our opinion, nearly as high as can be reasonably expected. In Prussia, where it is compulsory, it is 1 in 6.27; in England and Wales it is, as we have seen 1 in 7.7; in Holland it is 1 in 8.11; in France it is 1 in 9.0. The presence of this proportion of the population in school implies (as is shown by the foregoing calculations) that almost every one receives some amount of school education at some period or other ... ${ }^{47}$ 
It is interesting to note the similarities between the survey and census data from the Madras Presidency in India as stated in the Adam Reports compared with the Newcastle Commission's findings in England and Wales. Private schools provided an education for the majority of children. In both cases it was advised that the current status quo should not be meddled with and that the private sector be encouraged to expand. But just as Thomas Babington Macaulay was entering stage right, ignoring the entire plot of what had been shown by the survey and census data in India, enter stage left W.E. Forster.

In England Forster was almost totally to ignore the findings of the Newcastle Commission, which had taken three years to produce, using five commissioners and ten assistant commissioners. Forster instead relied on evidence from a small-scale study, which took a few months to complete, in four towns, by two inspectors, J.G. Fitch and D.R. Fearon in 1869. Discrepancies between the data presented to Forster and in the Newcastle Commission stem from the fact that the small-scale study takes as given the school age to be from 5-13 years, that is eight years of schooling. However, the Newcastle Commission interprets school age as 5-11 years, so only six years (or in fact, as it was, 5.7 years). The school leaving age was not raised to 12 years old until 1899 and therefore the Newcastle Commission is in fact accurate. The study used by Forster from Fitch and Fearon showed children to be missing from school when in fact they were not supposed to be in school above the age of 11 years anyway. Irrespective of the discrepancy, Forster's 1870 Bill was introduced. According to James Tooley it was meant:

explicitly as a measure to cater for those children who were not being provided by existing voluntary measures. It was not designed to cater universally for all children, but only to fill in the gaps in the current private system ... Forster was aware that voluntary private provision was a very valuable resource in educational provision, and simply needed to be supplemented by his new board schools as required, not replaced. ${ }^{48}$

So, just as in India, before the state intervened in education there was a vibrant schools' market operating in England and Wales, catering for the majority of school-aged children. State intervention initiated through the 1870 Act was only meant to fill in the gaps, not replace it. But, at the time, there were some critics of private schools, especially regarding quality, who would have been happy to see the system replaced. Just as with Hartog and Macaulay, what were their arguments to try to dismiss the private sector? 


\section{Quality}

As in India, in England there were those who questioned the quality of the private schools, especially with respect to the teachers who typically had no teacher training. Even though parents at the time were happy to pay for their children to be taught by untrained teachers, some advising the government regarded teachers to have 'picked up' their knowledge 'promiscuously'. ${ }^{49}$ According to Mr Cumin who was concerned about the mushrooming of private schools in the 1850s and as he set out his concerns in the Royal Commission on Popular Education of 1861:

Of the private school masters in Devonport, one had been a blacksmith and afterwards an exciseman, another was a journeyman tanner, a third a clerk in a solicitor's office, a fourth (who was very successful in preparing lads for the competitive examination in the dockyards) keeps an evening school and works as a dockyard labourer, a fifth was a seaman, and others had been engaged in other callings. ${ }^{50}$

This, therefore, Mr Cumin believed was an illustration of the poor quality of teaching. However Mr Cumin need not have been concerned because parents were well aware that some teachers could try to hoodwink them by not being up to par. But as argued by West, parents were shrewd and could detect and reject such 'quacks'. ${ }^{51}$

The teacher training of the day shows an obsession with learning by rote. In the Royal Commission on Popular Education of 1861 a Mr Altick comments thus:

the institutions that fed teachers into the expanding elementary school system were pedant factories, whose machinery efficiently removed whatever traces of interest in human culture the scholars had somehow picked up earlier in their careers. ${ }^{52}$

West makes the point that Mr Cumin's concerns may have been unfounded and agrees with $\mathrm{Mr}$ Altick that children were probably more inspired by the professionally eclectic teachers in the private schools who still retained their own personality and experience whilst teaching, as opposed to the trained teachers teaching by rote with their young wards repeating parrot fashion paragraphs to be memorised.

Even so, the lack of teacher training is not an argument for the introduction of the Board School through the 1870 Act. A rule could have been passed where private school teachers were required to undertake some training. But with regard to quality, it was the parents, paying fees, who were the inspectors of the private schools, being able to withdraw 
their children from a school they felt inefficient. Parents felt they needed to pay for schooling in order for it to be accountable to them and maintain efficiency. Evidence from the day shows that the majority of parents could pay and wanted to pay for schooling, according to the Newcastle Report:

Almost all the evidence goes to show that though the offer of gratuitous education might be accepted by a certain proportion of the parents, it would in general be otherwise. The sentiment of independence is strong, and it is wounded by the offer of an absolutely gratuitous education..$^{53}$

\section{After 1870 - Unfair Competition}

Between 1833 and 1870 schools could be funded in three ways: by subscriptions, fees or state subsidies. After 1870 an additional method was introduced, that of being funded by the local rate, which was a property tax. School boards were to look for gaps, either where private schools were not operating or where private provision was of low quality and hence 'inefficient', in order to set up a new Board School. Private schools now faced new unfair competition as Board Schools, funded through the rates, could drop their fees below those of the private schools. Parents were now also paying rates to support the Board Schools and had less disposable income, thus having to make new choices with regard to school spending. Private schools were being forced out of business, being crowded out by the cheaper public alternative. The letter quoted below is from a rector, whose schools (the St Paul's Church of England schools) were to be taken over by the new board as they were deemed to no longer be 'flourishing' and hence had declined in quality. They were no longer 'flourishing' because they were facing competition from a Board School in the same street, which was providing education at a lower cost to parents and giving students free books and slates. As in his letter of 1876 to the Manchester School Board the rector explains:

Let it not be imagined that I am opposed to giving a cheap and good education to the people, if their circumstances require it, I would gladly aid to the utmost of my power in providing for the education of their children at the lowest possible charges. But I submit that their circumstances do not require it. They are well able to pay, as they have done heretofore, $6 \mathrm{~d}$ and $8 \mathrm{~d}$ per week ... I would ask whether it is right to pay out of the public rates for the education of children where parents are well able to pay for themselves? And is it right to members of Christian Churches, which have made great sacrifices of time and money to erect schools in connection with their places of worship, to set up rival schools which, as ratepayers, they are compelled to support, in addition to their having to support their own denominational schools? ${ }^{54}$ 
The unfair competition continued where funding could be increased to the Board Schools through public revenues. Section 54 of the Education Act 1870 allows for 'any sum required to meet any deficiency in the school fund, whether for satisfying past or future liabilities, shall be paid by the rating authority out of the local rate'. ${ }^{55}$ The Board Schools drove out the private ones, propped up by taxation, irrespective of quality, patronised by parents who could no longer afford to pay private school fees in addition to the new taxes. What started out as a minor intervention in order to allow for universal education by filling in the gaps, gathered momentum.

Why?

West uses public choice theory to assert that those driving the idea of the new Board Schools were acting in self-interest, wishing to maximise the size, power and influence of the education bureau. According to West and public choice theory, those working in the bureau will want their budget to expand and if the budget of the bureau:

can be expected to expand faster with the gradual establishment of a universal system of public schooling that benefits the children of middle income parents as well as the poorest, this system will be 'pushed' ... even if the poorest would do better in a smaller selective system wherein all the benefits went to them exclusively. ${ }^{56}$

The interests of the poor will be overtaken by the self-interest of those working in the education bureau. It was made explicit in 1870 through the Bill presented by W.E. Forster that it was of the utmost importance not to destroy the private schools' system that already existed. However, this was not to be the case as the private schools were crowded out, and according to West 'the actual events, it seems, were much more the consequence of discretionary bureau behaviour' than Parliament had wanted. ${ }^{57}$

\section{SUMMING UP}

What this chapter has shown is that in both nineteenth-century England and India an indigenous private school system existed without state intervention. In India in the 1820s and 1830s children were getting an education, some in 'school', others at home, the same in England. By the 1850s almost every child was in school. And in both cases, when the survey and census data were being collected the most important message conveyed was that care must be taken not to tamper with all that was good in the existing private system.

According to Munro, in India 'everything of this kind ought to be carefully avoided, and the people should be left to manage their schools in 
their own way'. And in England, Forster along with others reiterated that it was important not to destroy the private system but just to fill in any gaps if they existed. To re-quote Henry Brougham, 'it behoves us to take the greatest care how we interfere with a system which prospers so well of itself'. 58

But it was not to be. In both India and England the whole government process steamrollered ahead and over what already existed, replacing it over the years with a virtually monopolistic government school system, funded, regulated and provided by the state. The message here is that all that was good was destroyed, crowded out, not able to compete. Even when those initially involved in a process to discover how children were being educated had indicated otherwise.

The following chapter investigates another kind of intervention by developed country governments, the giving of international aid. It asks: is bilateral and multilateral aid - known as systematic aid - making a positive difference to the lives of the poor? Its main focus is on India and schooling, but to begin the general debate regarding the why and how of aid giving is considered.

\section{NOTES}

1. Hartwell (1995), p. 42.

2. Tooley (2008), p. 123.

3. Dharampal (1995), p. 6.

4. Ibid.

5. Ibid.

6. Ibid.

7. Ibid., p. 90.

8. Ibid., p. 89.

9. Ibid.

10. Ibid.

11. Ibid., p. 90.

12. Ibid.

13. Ibid., pp. $18-19$, pp. $34-5$.

14. Adam (1841), p. 268, emphasis added; Leitner (1883), p. 349; cited in Dharampal (1995), p. 12.

15. Adam (1841), cited in Dharampal (1995), p. 6.

16. Ibid., p. 7.

17. Dharampal (1995), p. 18.

18. Ibid., p. 143; Cooke's data collected in 1823.

19. 1 anna $=1 / 16$ of a rupee.

20. Dharampal (1995), p. 273.

21. Ibid., p. 233.

22. Ibid., p. 99.

23. Ibid., p. 129.

24. Ibid., p. 132.

25. Ibid., p. 160. 
26. Ibid., p. 147.

27. Ibid.

28. Ibid., p. 270.

29. Ibid., p. 274.

30. Ibid., p. 279.

31. Ibid., p. 375.

32. Grey (2010).

33. Ibid., p. 90.

34. Young (1957), p. 729.

35. The Economic Times of India, Bombay edition, 31 January 1966.

36. Tooley and Stanfield (2003), p. 24.

37. West (1994), third edition of Education and the State, p. 158.

38. The Report of the Poor Law Commissioners (1841), cited in West (1994), p. 161.

39. Minutes of the Committee of Council on Education (1840-1841), cited in West (1994), p. 161.

40. Report on the State of Education in the Borough of Kingston upon Hull, Journal of the Statistical Society of London, July 1841, in West (1994), pp. 162-3.

41. West (1994), p. 165.

42. Ibid., pp. $170-1$.

43. Brougham (1835), quoted in West (1994), p. 173.

44. Census 1851, pp. 134-5, cited in West (1994), p. 175.

45. Education Commission, Report of the Commissioners Appointed to Enquire into The State of Popular Education in England, Vol. I (1861), p. 85, cited in West (1994), p. 178.

46. West (1994), p. 179.

47. Education Commission, Report of the Commissioners Appointed to Enquire into The State of Popular Education in England, Vol. I (1861), p. 293, cited in West (1994), p. 213.

48. Tooley (2008), pp. 94-5.

49. West (1994), p. 208.

50. The Royal Commission on Popular Education, Vol. 1 (1861), p. 93, cited in West (1994), pp. 208-9.

51. West (1994), p. 208.

52. Newcastle Commission, p. 162, cited in West (1994), p. 210.

53. Newcastle Report, p. 73, cited in West (1994), p. 213.

54. West (1994), pp. 197-8.

55. Ibid., p. 193.

56. West (1975), p. 63.

57. Ibid., p. 72.

58. Brougham (1835), quoted in West (1994), p. 173. 